\title{
Identifying Students' Conceptual Profile on Science Through Series Electrical Circuits Conceptual Survey with Four-Tier Diagnostic Test
}

\author{
Reza Hesti ${ }^{1 *}$
}

\author{
${ }^{1}$ MTsN 32 Jakarta, Jakarta, Indonesia \\ *Corresponding author.Email: RezaHesti@mtsn32jakarta.sch.id
}

\begin{abstract}
Series Electrical Circuit material is one of the basic materials in physics. Despite its applications in everyday life literacy, many electrical concepts are abstract so they are difficult to learn. Many students have difficulty in understanding the concept. Therefore, a diagnostic test instrument is needed to diagnose the concept of Series Electrical Circuit of the students. Researcher has developed the Series Electrical Circuit Survey (SECCS) instrument test into a four-tier test of diagnostic items. The purpose of this research is structured as the first step of the development of the SECCS four-tier test format as a diagnostic test instrument. The research method used is a 4D model (Defining, Designing, Developing and Disseminating). The developed instrument has been tested on 32 students in Madrasah Tsanawiyah (secondary level). The results of the study show that the development of SECCS in the form of a four-tier test has good validity and reliability and may be able to identify the category of students' level of conception, namely students who understand concepts, understand but partially, misconceptions and do not understand the concept of simple electrical circuits at all.
\end{abstract}

Keywords: Series electrical circuit, Four-tier diagnostic test, conception, Literacy.

\section{INTRODUCTION}

The framework of a conception is a network of interrelationships between concepts and will provide a comprehensive understanding of a phenomenon. Key features of the framework of a conception [1], as follows:

- a conceptual framework is not just a collection of concepts but a construction of each concept that plays a role as a whole;

- the framework of a conception provides an approach related to social reality;

- conceptual framework provides an understanding of something; and

- conceptual frameworks can be developed and constructed through a qualitative analysis process.

Analysis of a conception usually aims to generate concepts and ideas. According to [2], conception is the ability to understand concepts, both concepts obtained through interaction with the environment and those obtained from formal education.

If there is a misconception from students, they will transfer the misconception to the next level of learning and may lead to other misconceptions. The educational process at a high level will be affected so as to produce a person with a low level of professional life. Constructivism views it as important to overcome the misconceptions that students have and believe because their conceptions are different from scientific concepts; it is latent and continues to be used by students and tends to be difficult to change; and it is difficult to be detected by the teachers [3].

In the level of understanding, students learn something from reading activities, discussions, practical activities, and may answer questions about the previously stated concepts so that students may develop their ability to reasoning and finally reach an understanding of the concepts they have learned. There are five levels of understanding that students obtain from the learning process [4], namely:

- Good concept understanding (S). At this level, students have complete knowledge of a concept and are able to appropriately apply the concept to new situations they face. 
- The concept is partially understood (P). At this level, students understand the concept correctly but incompletely.

- Students often understand the concept partially, giving rise to a partial misconception (Specific Misconception / SM).

- Students do not understand the material being taught and specific misconceptions are developed when the new material is combined with the knowledge already possessed by previous students.

To obtain meaningful learning, conceptual understanding needs to be supported by problem-solving, and conceptual understanding is more important than memorizing concepts [5]. According to cognitive theory, students construct a reasonable and coherent understanding of phenomena that exist in nature from their point of view. For better understanding and obtaining meaningful learning, misconceptions may affect students' learning about scientific concepts so they should be rehabilitated. While the best learning is seen as a process of changing conceptions [6], So a change of a conception is considered as a modification or rejection of a person's conception of beliefs when presented in an anomalous situation [5] [7]. To eliminate misconceptions and achieve meaningful learning and review the accuracy of knowledge, misinformation should be changed to give potential for new knowledge, this process is called changing conception [8].

A teacher may help change the conception of the students, one of which is through assessment with diagnostic tests. The assessment is an important aspect for the teacher to employ because it may serve as a source of meaningful information to determine the quality of teaching and assist the teachers in determining the appropriate strategies in their class. Records gained from the student's learning progress can also be obtained from the results of the assessment; diagnostic tests are part of the assessment used to map student's strengths and weaknesses and provide input to the teachers and students to make decisions related to improving the teaching and learning process [9]. Diagnostic tests in the form of multiple choice are often used because they can reach a large number of respondents [3].

Among the advantages of multiple-choice diagnostic tests, there are several disadvantages [3], [10]-[13], namely:

- It is possible to guess the answer.

- The answer choices given do not likely provide broad insight into students' ideas and understanding of their conceptions.

- Students are forced to choose answers among the limited answer choices, preventing students from constructing, organizing, and presenting their own answers.

- It cannot distinguish the right answer from the right reason and the right answer from the wrong reason.
To avoid the possibility of correct answers from wrong reasons (false positives) and wrong answers even though students have the right reasons (false negatives), and to emphasize the importance of accuracy in the act of selecting multiple-choice tests, it was developed multiple choice diagnostic test with graded form.

Various diagnostic test instruments on Physics concepts to determine students' level of conception have been developed by many researchers [12], [14], [15]; [16]. In order to overcome the shortcomings of the multiple-choice diagnostic test or one tier test, a two-tier test and a three-tier test have been developed. In the end, to overcome the shortcomings of the three-tier test, the researcher has developed a four-tier test [12], [14], [17]. The four-tier test structure consists of tier-1 in the form of questions, tier- 2 in the form of the level of confidence in the answers to tier- 1 , tier- 3 in the form of reasons for the answers from tier- 1 and tier- 4 is the level of confidence in the reasons for answers in tier-3 [18], [19].

The four-tier diagnostic test format is used to diagnose students' level of conception on a Physics concept. There are several diagnostic test instruments used to identify students' level of conception on concepts in Physics including the concepts of Temperature and Heat [18], [20]-[22], Dynamic fluid [23], [24], Energy and Momentum [19], Optical Instruments [25], Vibration [26], hydrostatic [27], and Ocean Pollutant Migration [28].

There are four-tier diagnostic tests on some Physics concept materials that have been made by researchers, but no one has made them on Series Electrical Circuit material. Even though the material is a basic material in Physics, its application covers many aspects of everyday life. In addition, the concepts of Physics in the field of electricity, including Series Electric Circuits, are invisible, making it difficult to learn. Not a few students, student teacher candidates and Physics teachers have difficulty in understanding the electrical concepts, especially in electrical circuits. The difficulty experienced by students, prospective teacher students and Physics teachers to understand a concept may lead to misconceptions [29], [30]. Students who experience misconceptions in physics learning are in fact an important spotlight because of the dangers of resistant misconceptions and will lead to new misconceptions at a higher level of learning. Thus, students who experience misconceptions need to experience a change of conception appropriately in order to gain new scientific knowledge about physics concepts. Therefore, a diagnostic test is needed that is able to describe the conceptual profile of the Serial Electrical Circuit material experienced by students in the form of four-tier test as a development and refinement of the diagnostic test of onetier test, two-tier test and three-tier test. 


\section{METHODS}

This is a development research on the four-tier diagnostic test instrument which is used to identify the student's conception of profile literacy on the Series Electrical Circuit material. The development model used is 4D [31], which consists of four stages, namely defining, designing, developing, and disseminating. The data analysis was carried out through validity, reliability, and identification of the student's conception profile on the Series Electrical Circuit material.

Before the instrument was tested, it was initially analyzed using CVR (Content Validity Ratio) [32]. The scoring of the answer items uses the CVR method which is a content validity approach to determine the suitability of the items with the domain measured based on the experts' judgment. The validity of the instrument in the form of content validity was carried out by asking the experts for consideration and the trial was conducted at one of the madrasah in Jakarta, namely students who had studied Electrical Circuit material in the same class but different from the class for which the conception profile will be taken.

The technique used to determine the reliability of the test in this study was to use the single test double trial technique, which is to test the same instrument twice. Then the results of the first and second tests are correlated to determine the reliability index. To determine the correlation coefficient used the product moment correlation formula proposed by Pearson. After obtaining a valid instrument in the form of a Series Electric Circuit conception test instrument consisting of six questions, the questions were tested on ninth grade students in one of the junior secondary madrasahs in Jakarta, a total of 32 participants who had studied the material in Series Electric Circuits and experienced misconceptions to take a conceptual profile.

Meanwhile, the analysis of the conception profile was carried out by interpreting it based on the combination of student's answers on the four-tier diagnostic test. The student's conception profile was divided into five categories which were adapted from Samsudin, et al [22], namely Sound Understanding (SU) is the state of students who have a correct and complete understanding of the concept, Partial Understanding (PU) is the state of students who only have a partial understanding of the concept and cannot explain a phenomenon entirety, No Understanding (NU) is the state of students who do not understand the concept, Misconception (MC) is the state of students who have conceptions that are not in line with existing scientific concepts and Un-coded (UC) namely students whose condition cannot be understood. The combination of answers to the four-tier diagnostic test is presented in Table 1.
Table 1. Combination of four-tier diagnostic answers test

\begin{tabular}{|c|c|c|c|c|}
\hline Tier-1 & Tier-2 & Tier-3 & Tier-4 & $\begin{array}{l}\text { Conceptual } \\
\text { Profile }\end{array}$ \\
\hline 1 & $S$ & 1 & $S$ & \multirow{6}{*}{ SU } \\
\hline 1 & $S$ & 1 & NS & \\
\hline 1 & NS & 1 & $S$ & \\
\hline 1 & NS & 1 & NS & \\
\hline 1 & $S$ & 0 & $S$ & \\
\hline 1 & $S$ & 0 & NS & \\
\hline 1 & NS & 0 & $S$ & \multirow{6}{*}{ PU } \\
\hline 1 & NS & 0 & NS & \\
\hline 0 & $S$ & 1 & $S$ & \\
\hline 0 & $S$ & 1 & NS & \\
\hline 0 & NS & 1 & $S$ & \\
\hline 0 & NS & 1 & NS & \\
\hline 0 & $S$ & 0 & NS & \multirow{3}{*}{ NU } \\
\hline 0 & NS & 0 & $S$ & \\
\hline 0 & NS & 0 & NS & \\
\hline 0 & $S$ & 0 & $S$ & $M C$ \\
\hline \multicolumn{4}{|c|}{$\begin{array}{l}\text { If one, two, three, } \\
\text { or everything is not filled }\end{array}$} & UC \\
\hline
\end{tabular}

Description: $\mathrm{SU}=$ Sound Understanding; $\mathrm{PU}=$ Partial understanding; $\mathrm{MC}=$ Misconceptions; $\mathrm{NU}=\mathrm{No}$ understanding; UC $=$ Un-coded; $1=$ correct answer; $0=$ wrong answer; $\mathrm{S}=$ Sure; NS = Not sure

\section{RESULTS AND DISCUSSION}

\subsection{Defining}

The development of the SECCS instrument in the four-tier test format began with defining which test instrument that can be used to diagnose the level of students' conception of the Series Electric Circuit Concept (SECCS). SECCS is an extension of the two-tier diagnostic test. The development is found in the addition of the level of student confidence in choosing answers and reasons, namely:

- The first level (one-tier) or also called the answer tier (answer tier) is the level that presents the answer choices for the questions/problems posed.

- The second level (two-tier) is a level that presents various confidence scales to measure to what extent the students are confident in determining and choosing the answers at the first level. 
- The third level (three-tier) or also called the level of reason (reason-tier) is a level that presents the reasons that students should choose regarding determining answers at the first level.

- The fourth level (four-tier) is a level that presents various confidence scales to measure to what extent the students are sure in determining and choosing answers at level three.

\subsection{Designing}

After the definition, the SECCS diagnostic test instrument was designed in the four-tier test format. The design of the SECC instrument which was originally only in the form of a two-tier test as shown in Fig 2a became a four-tier test format as shown in Fig $2 b$.

\begin{tabular}{|l|}
\hline Question \\
\hline Answer Choice \\
a. \\
b. \\
c. \\
e. \\
\hline Reason \\
\hline
\end{tabular}

Figure 1 Two Tier Test.

\begin{tabular}{|l|}
\hline Question \\
\hline Answer Choice \\
a. \\
b. \\
c. \\
d. \\
e. \\
\hline Are you satisfied wth your answers? \\
a. Sure \\
b. Not Sure \\
\hline Reason \\
a. \\
b. \\
c. \\
d. \\
e. \\
\hline Are you satisfied wth your answers? \\
a. Sure \\
b. Not Sure \\
\hline
\end{tabular}

Figure 2 Four Tier Test.

\subsection{Developing}

The validity test was carried out by experts, consisting of five lecturers of Physics by assessing material aspects, construction aspects, language aspects, and the suitability between tier- 1 and tier- 3 on the instrument. The validity test obtained from the experts is in the category of percentage validation score of $66.7 \%$ (enough) which means the instrument can be used as a diagnostic test.

In addition to the validity test, the reliability instrument test was also carried out, from the results of the analysis of the student's test and re-test answers, the reliability score of the instrument for changing the conception of Series Electric Circuit was 0.6 which was in the strong (good) category. It can be stated that the instrument is reliable and can provide data in accordance with reality.

The following is part of the instrument used in the study consisting of six questions shown in Fig 3 .

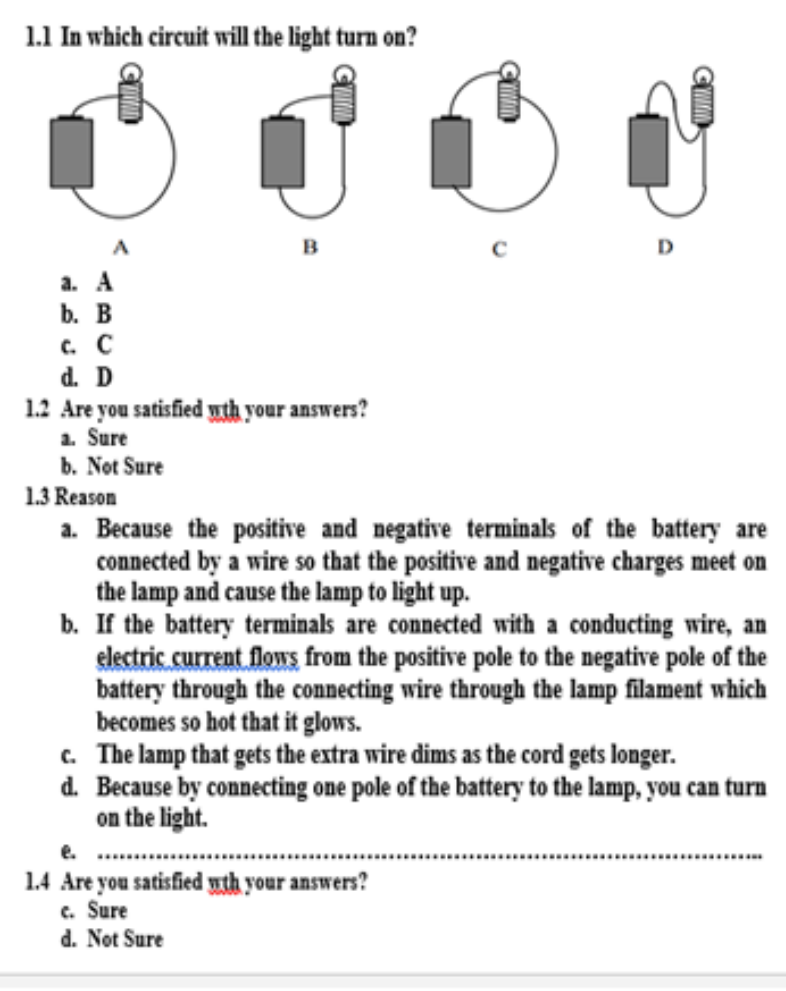

Figure 3 Sample of SECCS four-tier diagnostic test

\subsection{Disseminating}

The instrument was disseminated in the evaluation of the online learning process for Series Electrical Circuits. There were 32 students in one class whose level of conception would be identified. The dissemination stage took one session consisting of 60 minutes. The results of the research data were categorized into five categories, namely Sound Understanding (SU), Partial Understanding (PU), No Understanding (NU), Misconception (MC) and Un-coded (UC), which is 
presented in Fig 4. It can be concluded that the level of students' conception of the concept of Series Electrical Circuits are quite good. It shows the second lowest percentage of misconceptions from all levels of student conception of $1.4 \%$. On the other hand, the condition of $\mathrm{SU}$ is at the highest level, namely $57 \%$, meanwhile PU is $16.9 \%$, NU is $25 \%$ and $\mathrm{UC}$ is $0 \%$.

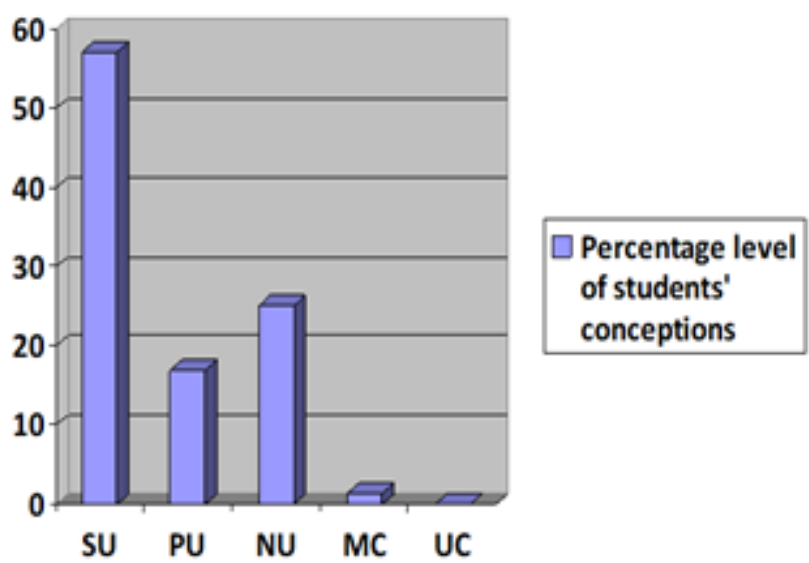

Figure 4 The category of students' level conceptions.

\section{CONCLUSION}

The results corroborate the four-tier diagnostic test instrument is categorized valid and reliable. The instruments being developed may also identify students' conception profiles on the Series Electrical Circuit material with students' conception profiles divided become Sound Understanding (SU), Partial Understanding (PU), No Understanding (NU), Misconception (MC), and Un-coded (UC). It is expected that teachers be able to improve and provide appropriate Physics teaching methods in class so that the learning process is more meaningful.

\section{AUTHOR CONTRIBUTIONS}

The author conceived and designed this study and contributed to the process of revising the manuscript, and at the end, the author has approved the final version of this manuscript.

\section{ACKNOWLEDGMENTS}

The author would like to thank for the input given from Mr. Dr. Johar Maknun, M.Si and Mrs. Dr. Selly Feranie so that this research could be carried out. I would also like to thank the madrasah principals and teachers who have assisted the process of carrying out this research.

\section{REFERENCES}

[1] E.H. Tamene, Theorizing conceptual framework, Asian Journal of Educational Research, 4(2) (2016) $50-56$.

[2] P. Suparno, Miskonsepsi dan perubahan konsep dalam pendidikan fisika. Jakarta, Grasindo, 2013.

[3] D.K. Gurel, A Review and Comparison of Diagnostic Instruments to Identify Students' Misconceptions in Science, Eurasia Journal of Mathematics, Science \& Technology Education, 11(5) (2015) 989-1008.

[4] N. Ültay, The effect of concept cartoons embedded within context-based chemistry: chemical bonding, Journal of Baltic Science Education, 14(1) (2015) 96-108.

[5] G.J. Posner, K.A. Strike, P.W. Hewson, W.A. Gertzog, Accomodation of a Scientific Conception: Toward a Theory of Conceptual Change, Science Education, 66(2) (1982).

[6] S. Sevim, Promoting conceptual change in science which is more effective: conceptual change text or analogy?, Journal of Turkish Science Education, 10(3) (2013) 24-36.

[7] S. Vosniadou, Reframing the classical approach to conceptual change: preconceptions, misconceptions and synthetic models, Dordrecht: Springer, 2012, 24.

[8] E. Çil, Teaching nature of science through conceptual change approach: conceptual change texts and concept cartoons, Journal of Baltic Science Education, 13(3) (2014) 339-350.

[9] Z. Zhao, An Overview of Studies on Diagnostic Testing and its Implications for the Development of Diagnostic Speaking Test, IJEL, 3(1) (2013) p41. DOI: 10.5539/ijel.v3n1p41.

[10] A. C. Dindar, O. Geban, Development of a three-tier test to assess high school students' understanding of acids and bases, Procedia Social and Behavioral Sciences, 15 (2011) 600-604..

[11] Z.D. Kirbulut, O. Geban, Using three-tier diagnostic test to assess students' misconceptions of states of matter, Eurasia Journal of Mathematics, Science \& Technology Education, 10(5) (2014) 509-521. DOI: 10.12973/eurasia.2014.1128a.

[12] H. Pesman, A. Eryılmaz, Development of a threetier test to assess misconceptions about simple electric circuits, The Journal of Educational Research, 103(3) (2010) 208-222. DOI: 10.1080/00220670903383002. 
[13] Ü. Turgut, F. Gürbüz, G. Turgut, An investigation 10th grade students' misconceptions about electric current, Procedia Social and Behavioral Sciences, 15 (2011) 1965-1971..

[14] D.K. Gurel, A. Eryılmaz, L.C, A. McDermott, review and comparison of diagnostic instruments to identify students' misconceptions in science, Eurasia Journal of Mathematics, Science \& Technology Education, 11(5) (2015) 989-1008 DOI: https://doi.org/10.12973/eurasia.2015.1369a.

[15] M.A. Uyulgan, N. Akkuzu, Ş. Alpat, Assessing The Students' Understanding Related To Molecular Geometry Using A Two-Tier Diagnostic Test, Journal of Baltic Science Education, 13(6) (2014) 839-855. DOI: 10.33225/jbse/14.13.839.

[16] A.H. Anwar, N.Y. Rustaman, W. Purwianingsih, Development of three-tier diagnostic test instruments for detecting students' conception, Journal of Physics: Conference Series, 1318 (2019) 012064. DOI: 10.1088/1742-6596/1318/1/012064.

[17] I.S. Caleon, R. Subramaniam, Do Students Know What They Know and What They Don't Know? Using a Four-Tier Diagnostic Test to Assess the Nature of Students' Alternative Conceptions, Research in Science Education, 40(3) (2010) 313337. DOI: $10.1007 / \mathrm{s} 11165-009-9122-4$.

[18] A. Samsudin, A. Suhandi, D. Rusdiana, I. Kaniawati, Preliminary Design of ICI-based Multimedia for Reconceptualizing Electric Conceptions at Universitas Pendidikan Indonesia, Journal of Physics: Conference Series, 739 (2016) 012006, DOI: 10.1088/1742-6596/739/1/012006.

[19] N.F. Afif, M.G. Nugraha, A. Samsudin, Developing Energy and Momentum Conceptual Survey (EMCS) with Four-Tier Diagnostic Test Items, AIP Conference Proceedings, 2016, pp. 5. DOI: 10.1063/1.4983966.

[20] A. Eryilmaz, Development and Application of Three-Tier Heat and Temperature Test: Sample of Bachelor and Graduate Students, Eurasian Journal of Educational Research, 40(1) (2010) 53-76.

[21] A. Suhandi, N. Hermita, A. Samsudin, B.Maftuh, B. Coştu, Effectiveness of Visual Multimedia Supported Conceptual Change Texts on Overcoming Students' Misconception About Boiling Concept, The Turkish Online Journal of Educational Technology, (2017) 14

[22] A. Samsudin, A. Suhandi, D. Rusdiana, I. Kaniawati, B. Coştu, Promoting Conceptual Understanding on Magnetic Field Concept Through Interactive Conceptual Instruction (ICI) with
PDEODE*E Tasks, adv sci lett, Advanced Science Letters, 23 (2) (2017) 1205-1209. DOI: 10.1166/asl.2017.7539.

[23] F.H. Dewi, A. Samsudin, M.G. Nugraha, An investigation of students' conceptual understanding levels on fluid dynamics using four-tier test, Journal of Physics: Conference Series, 1280 (2019) 052037. DOI: $10.1088 / 1742-6596 / 1280 / 5 / 052037$.

[24] D.M. Kurniawati, F.U. Ermawati, Analysis Students' Conception Using Four-Tier Diagnostic Test for Dynamic Fluid Concepts, Journal of Physics: Conference Series, 1491 (2020) 012012, DOI: 10.1088/1742-6596/1491/1/012012.

[25] P. Rawh, A. Samsudin, M.G. Nugraha, Pengembangan Four-Tier Diagnostic Test Untuk Mengidentifikasi Profil Konsepsi Siswa Pada Materi Alat-Alat, Wahana Pendidikan Fisika, 5(1) (2020) 84-89.

[26] Z. Zaleha, A. Samsudin, M.G. Nugraha, Pengembangan Instrumen Tes Diagnostik VCCI Bentuk Four-Tier Test pada Konsep Getaran, Jurnal Pendidikan Fisika dan Keilmuan (JPFK), 3(1) (2017) 36. DOI: 10.25273/jpfk.v3i1.980.

[27] M.G. Purwanto, R. Nurliani, I. Kaniawati, A. Samsudin, Promoting the hydrostatic conceptual change test (HCCT) with four-tier diagnostic test item, Journal of Physics, 7.

[28] W. Sopandi, R. R. Sukardi, Using Four-Tier Diagnostic Tests to Understand the Conceptions Held by Pre-Service Primary School Teachers about Sea Pollutant Migration, Review of International Geographical Education Online, 10(2) (2020) 1329. DOI: 10.33403/rigeo.629388.

[29] M.-H. Chiu, J.-W. Lin, Promoting fourth graders' conceptual change of their understanding of electric current via multiple analogies, The Official Journal of the National Association for Research in Science Teaching, 42(4) (2005) 429-464. DOI: 10.1002/tea.20062.

[30] G. Ugur, R. Dilber, Y. Senpolat, B. Duzgun, The effects of analogy on students' understanding of direct current circuits and attitudes towards physics lessons, European Journal of Educational Research, 1(3) (2012) 211-223.

[31] Borg W R, Gall M D, Educational Research An introduction. NewYork: Longman, 1989.

[32] C. Ayre, A. J. Scally, Critical Values for Lawshe's Content Validity Ratio: Revisiting the Original Methods of Calculation, Measurement and Evaluation in Counseling and Development, 47(1) (2014). DOI: 10.1177/0748175613513808. 